\title{
CORRIGENDUM
}

\section{Suppression of inflammation-associated factors by indole-3-carbinol in mice fed high-fat diets and in isolated, co-cultured macrophages and adipocytes}

H-P Chang, M-L Wang, C-Y Hsu, M-E Liu, M-H Chan and Y-H Chen

International Journal of Obesity (2013) 37, 324; doi:10.1038/ijo.2012.207

Correction to: International Journal of Obesity (2011) 35, 1530-1538; doi:10.1038/ijo.2011.12

After the publication of this article, the authors noticed that the photos in Figure 1 were misused. The correct Figure 1 is shown here.

a

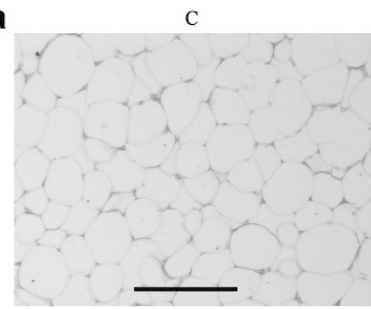

HF

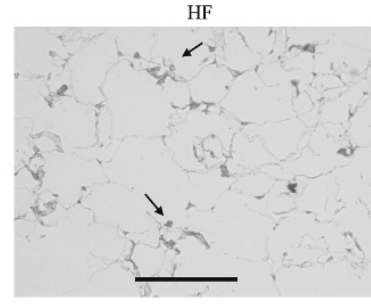

HFI

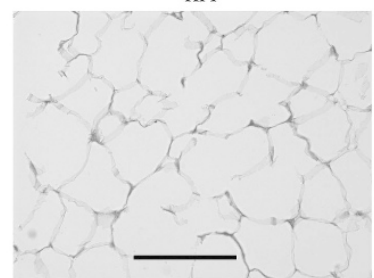

b

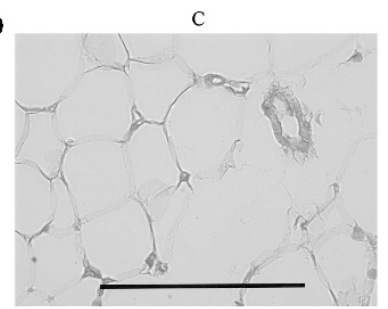

HF

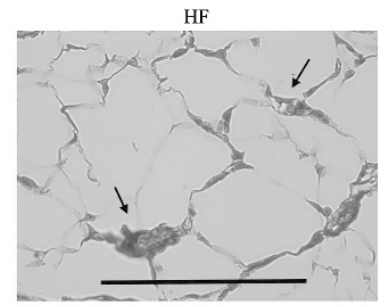

HFI

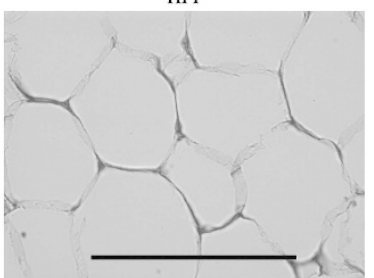

Figure 1. Effects of $\mathrm{I} 3 \mathrm{C}$ on $\mathrm{F} 4 / 80$ expression in epididymal adipose tissue (AT), $\times 200$ magnification (a) and $\times 400$ magnification (b), in animals fed different diets for 12 weeks (C, control diet; HF, high-fat diet; HFI, high-fat diet+intraperitoneally administered I3C). Immunohistochemistry detected a macrophage-specific antigen (F4/80) in epididymal AT from high-fat diet-induced obese mice. The black arrows showed abundant macrophages within AT. Macrophages were observed both near blood vessels and among large adipocytes. The scale bar represents $100 \mu \mathrm{m}$. 